\title{
Primary intrapulmonary neurogenic sarcoma with hypertrophic pulmonary osteoarthropathy and asbestosis
}

\author{
P. K. CAVES ${ }^{1}$ and J. JACQUES \\ Royal Victoria Hospital, Belfast
}

\begin{abstract}
A case of primary intrapulmonary neurogenic sarcoma with hypertrophic pulmonary osteoarthropathy and asbestosis is described. The essential histological features of this rare tumour are detailed, and the five authentic cases previously reported are reviewed. The pathogenesis of hypertrophic pulmonary osteoarthropathy and its occurrence in this case are discussed. After surgical removal of the tumour recurrence appeared in the chest within six months. It responded poorly to radiotherapy, and death from metastases occurred 16 months after operation.
\end{abstract}

Primary neurogenic sarcomas of the lung are among the rarest of tumours. While reports and reviews of intrapulmonary neurogenic tumours have appeared in the literature, very few reports of malignant tumours have been accompanied by adequate histological descriptions and photomicrographs. Diveley and Daniel in 1951 described the case of a 48-year-old man who died from recurrence of a primary neurogenic sarcoma of the left lung which had previously been treated by pneumonectomy. Santy, Galy, Touraine, and Uguat (1953), Petriat, Cornet, Legar, Castaing, and Tessier (1953), and Bartley and Arean (1965) each described a further case. Neilson (1958) added another case report and made an exhaustive review of the literature. $\mathrm{He}$ emphasized the need for adequate histological descriptions and photomicrographs in reporting all tumours of neurogenic origin, and particularly those arising in the lung, where anaplastic carcinomas can easily be confused with sarcomas. Other cases have been recorded but lack sufficient microscopical detail for the diagnosis of neurogenic sarcoma to be conclusive.

We wish to report a further case of primary intrapulmonary neurogenic sarcoma. It is of particular interest because of its production of hypertrophic pulmonary osteoarthropathy and its association with asbestosis. These two features have not previously been described.

\section{CASE REPORT}

A 43-year-old man was admitted to the Royal Victoria Hospital on 20 May 1969. He was a non-smoker.

1Present address: Brompton Hospital, London S.W.3
For 20 years he had been exposed frequently to asbestos dust in his job as a supervisor in the Belfast $\square$ shipyards. In January 1969 he first noticed pain in the right side of the chest, pleuritic in character. He was treated with penicillin and tetracycline but the pain persisted and he was admitted to another hos- $\frac{\varnothing}{\varnothing}$ pital at the end of March. The pain at the base of $\varnothing$ the right lung was severe and there was acute tender- $\overrightarrow{\vec{O}}$ ness and a loud pleural rub in this area. Grade II 3 clubbing of the fingers and toes was noted. A chest radiograph showed a shadow at the right base posterolaterally which was first thought to be an encysted effusion. Investigations showed haemoglobin $12.4 \mathrm{~g} \%$, ठิ white cell count $8,250 / \mathrm{mm}^{3}$, blood urea $22 \mathrm{mg} \%$, plasma proteins-albumin $3.25 \mathrm{~g}$, globulins $\alpha_{1} 0.55$, $\alpha_{2} 1.35, \beta 1.04, \gamma 1.19 \mathrm{~g} \%$, ESR $14 \mathrm{~mm} / \mathrm{hr}$ (Westergren).

In April he began to complain of pain and swelling $\varnothing$ in the wrist, elbow, ankle, and knee joints. The joint $₹$ pains steadily increased and further investigations $ᄋ$ showed: RA latex test, Rose-Waaler test, and LE latex test all negative. No LE cells were seen. Haemoglobin $11.0 \mathrm{~g} \%$, white cell count $11,300 / \mathrm{mm}^{3}, \mathrm{ESR}$ $35 \mathrm{~mm} / \mathrm{hr}$. Aspiration of the pleural cavity was $\mathcal{N}$ attempted but no fluid was obtained and a punch $N$ biopsy of the pleura was also unsuccessful. At this $N$ time a provisional diagnosis of pleural mesothelioma $\omega$ was made and he was transferred to the Royal? Victoria Hospital.

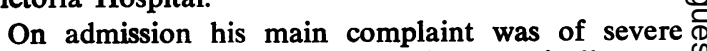
pain in the ankles and knees which practically con- $\stackrel{\infty}{+}$ fined him to bed. The chest pain had disappeared. On $\square$ examination he looked ill and had a temperature of $100-101^{\circ} \mathrm{F}\left(37 \cdot 7-38 \cdot 2^{\circ} \mathrm{C}\right)$. His face was pale and $\stackrel{\bigcirc}{\Phi}$ puffy and there was grade IV clubbing of the fingers $\vec{D}$ and toes. The knee and ankle joints were swollen $\varrho$ with effusions and the soft tissues around the ankles? were swollen and tender. Chest examination revealed $\delta$ 


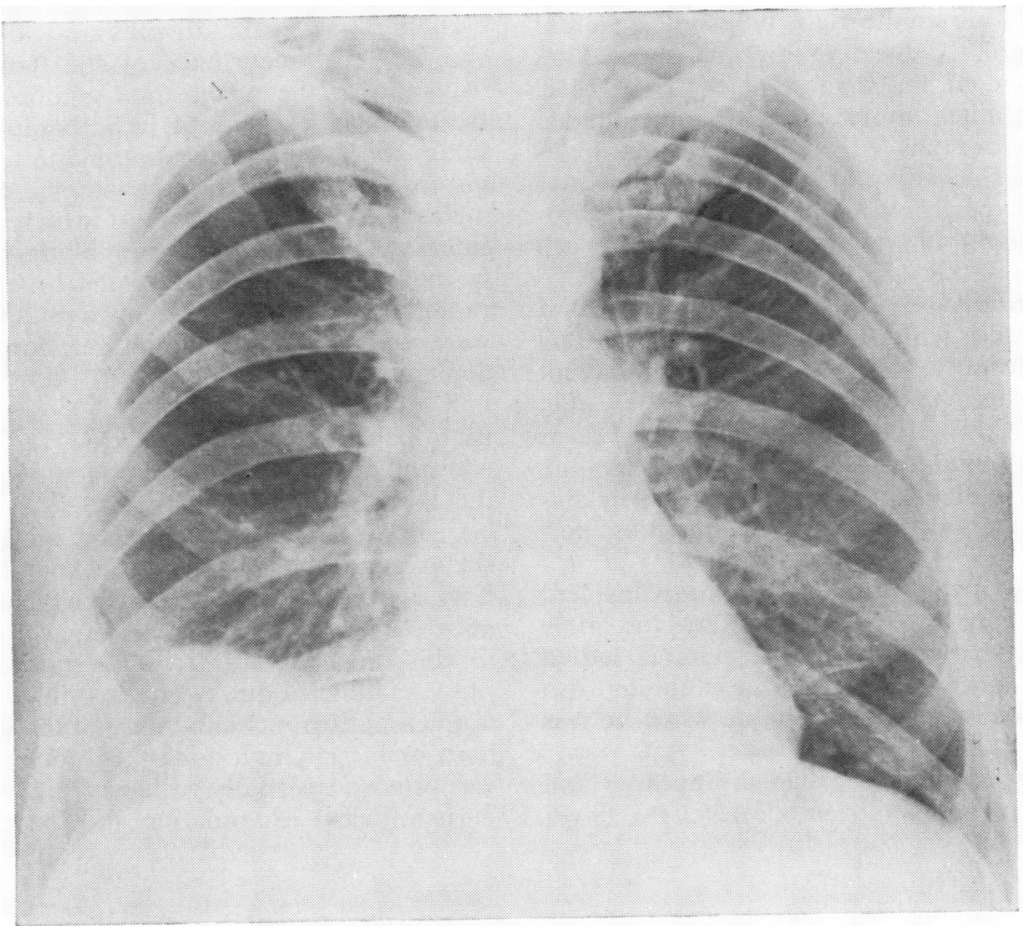

(a)

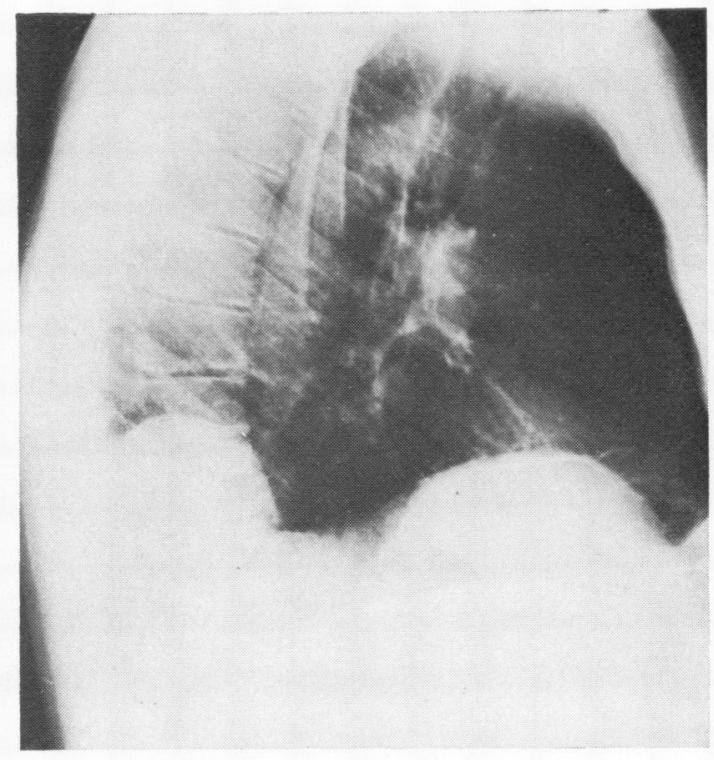

(b)

FIG. 1. Postero-anterior (a) and right lateral (b) radiographs of chest in May 1969, showing the tumour posteriorly at the base of the right lung. 
signs of consolidation at the right base but a pleural rub was not heard. A chest radiograph showed an increase in the size of the shadow at the right base, which was now much more discrete and rounded (Fig. 1) and radiographs of the knees and ankles showed periosteal thickening of the ends of the bones typical of early hypertrophic pulmonary osteoarthropathy. The haemoglobin was now $9.8 \mathrm{~g} \%$, white cell count $10,600 / \mathrm{mm}^{3}$, ESR $115 \mathrm{~mm} / \mathrm{hr}$.

Right thoracotomy on 2 June 1969 revealed a large, soft, lobulated, white tumour in the peripheral part of the right lower lobe. The tumour was adherent to the parietal pleura in the costophrenic angle. On the parietal pleura over the lower ribs and diaphragm there were several discrete, elevated, greyish, hyaline plaques, the largest of which was about $5 \mathrm{~cm}$ in diameter. An extrapleural lower lobectomy was performed.

On the evening of operation the joint pains had completely disappeared and within two days the joints appeared clinically to be normal. The pyrexia settled for the first time since admission. The clubbing also began to regress but was still detectable when he was discharged on 16 June 1969.

By August 1969 the clubbing had disappeared and he was well. However, in November 1969 the finger clubbing was again obvious and a chest radiograph showed local recurrence of the tumour in the chest wall and in the mediastinal glands (Fig. 2). He was treated with a course of radiotherapy $(2,400 \mathrm{rad}$ over three weeks) with symptomatic and radiological improvement. Two months later he developed further metastases in the right chest which caused him considerable pain. The finger clubbing became gross but he had no further joint pains or effusions. Further radiotherapy and treatment with cyclophosphamide were without effect and he deteriorated and died in September 1970.

PATHOLOGY The lobectomy specimen (Fig. 3) weighed $380 \mathrm{~g}$. The pleura was thickened around the base of the lobe and a few small nodules of tumour, up to $0.5 \mathrm{~cm}$ in diameter, were present on the diaphragmatic surface. In the periphery of the lobe there was an 8 by $5 \mathrm{~cm}$ tumour with a soft white whorled appearance. A few yellowish areas of necrosis were present in this, and around its edge there were occasional small satellite nodules. The neoplasm was not related to the major bronchi and did not involve the bronchial limit or hilar lymph nodes. The remaining lung tissue was firm and partially collapsed.

Histological examination showed that the tumour,

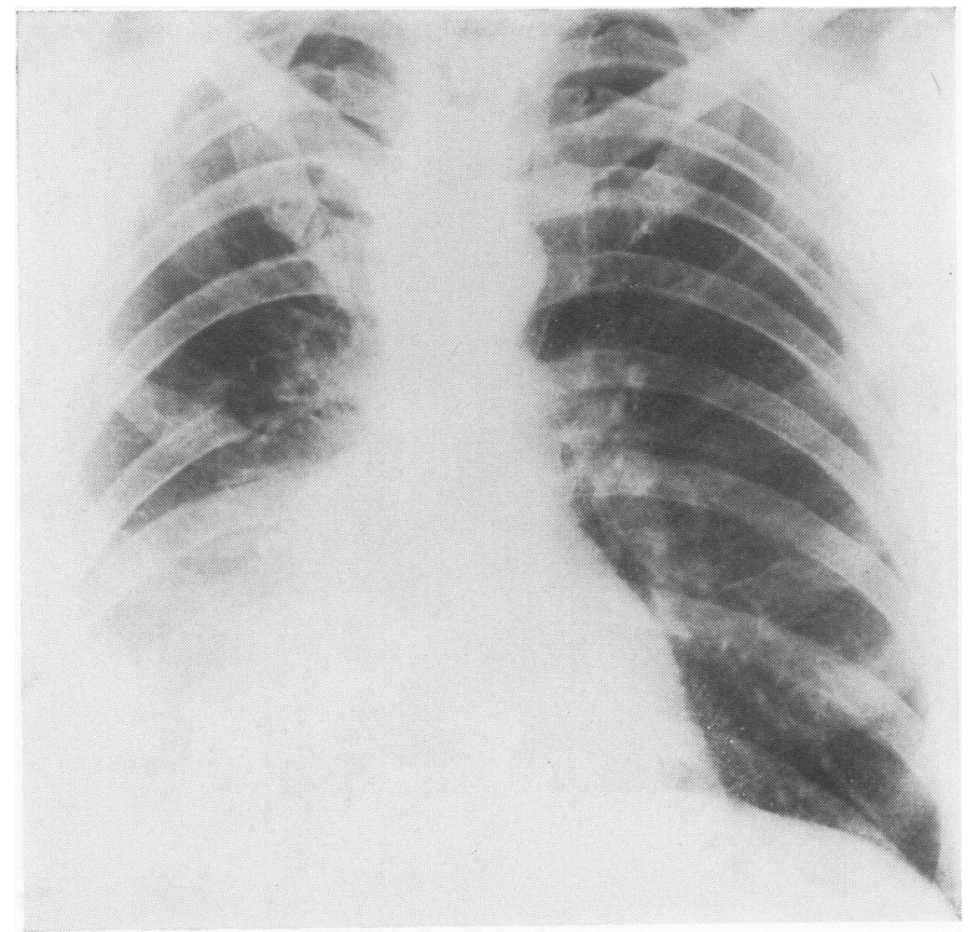

FIG. 2. Postoperative chest radiograph in November 1969, showing recurrence of the tumour locally and in the lower mediastinum. 


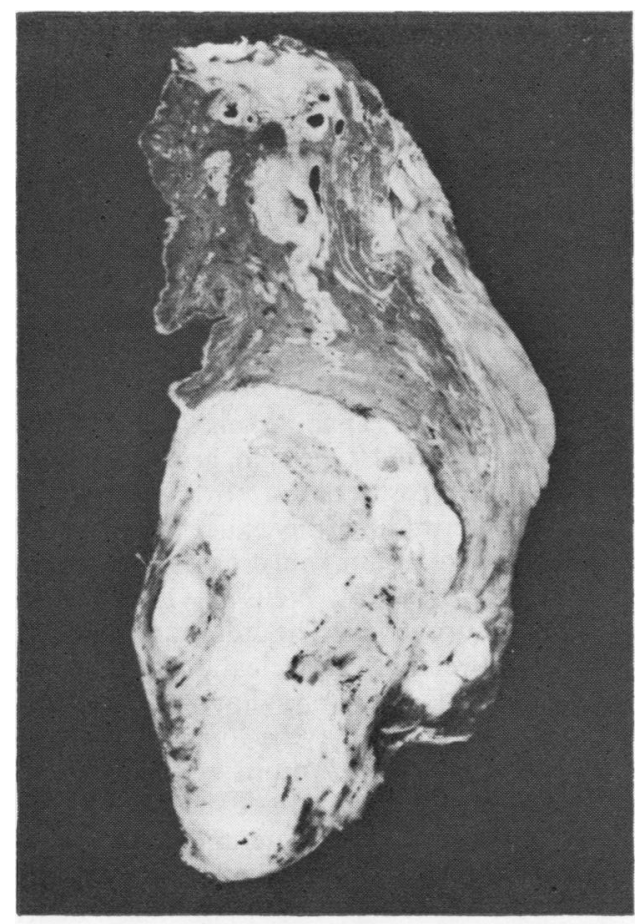

FIG. 3. Macroscopic view of right lower lobe showing cross-section of the neurogenic sarcoma.

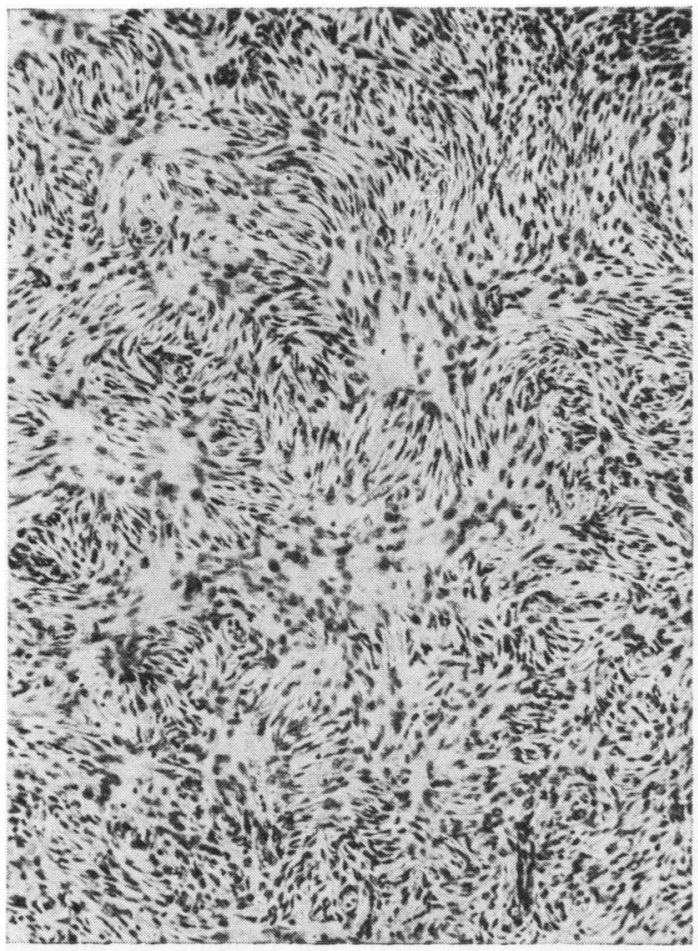

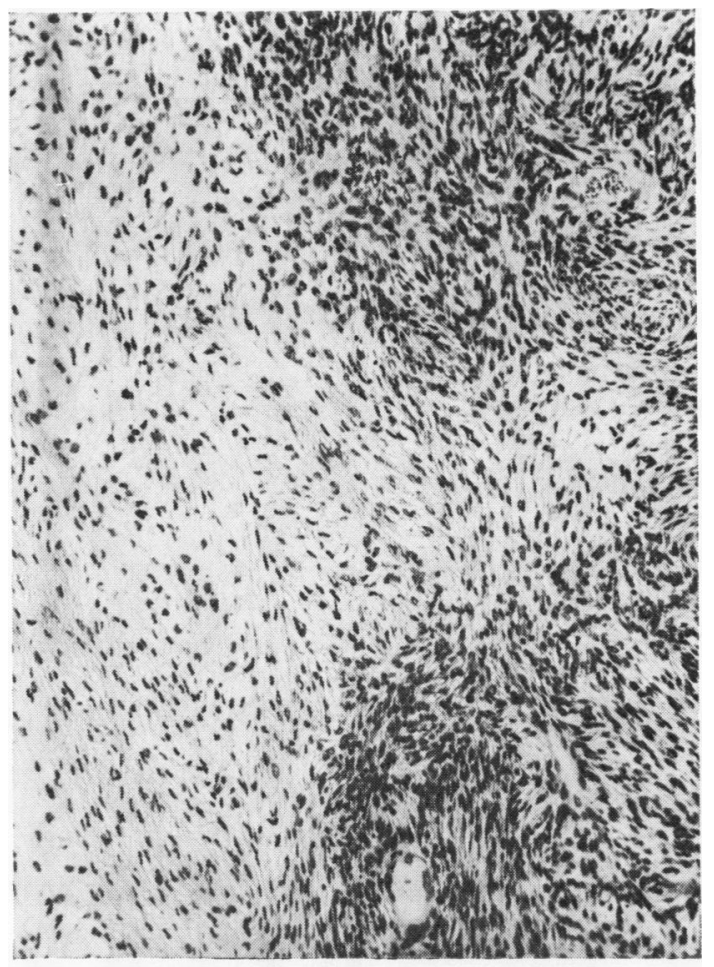

(b)

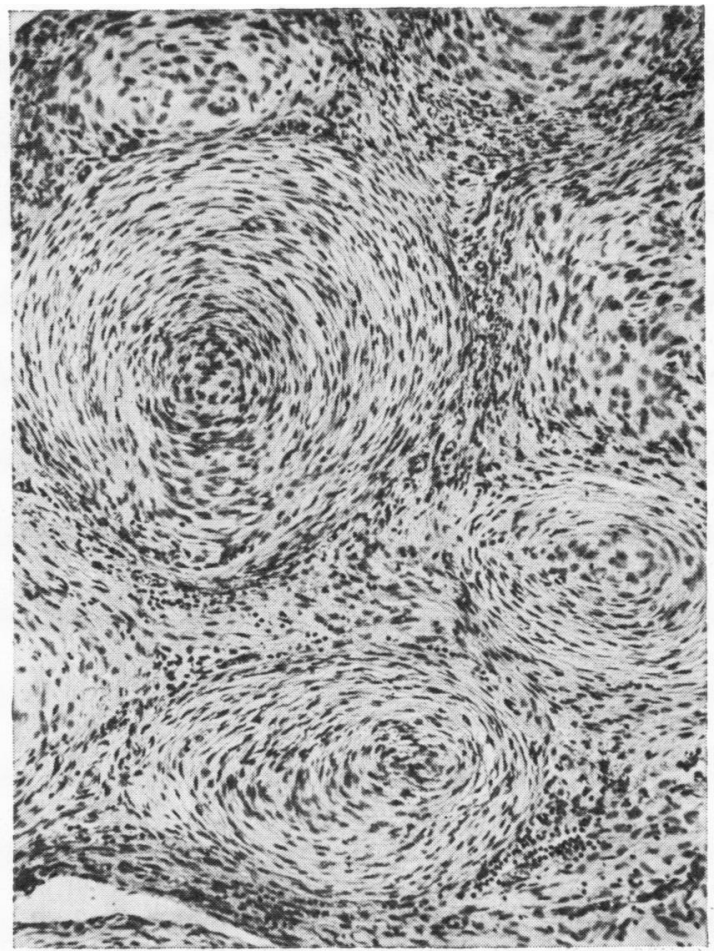

(c)

FIG. 4. Microscopical view of the neurogenic sarcoma $(H . \& E . \times 90)$; (a) spindle cells with nuclear regimentation and areas of palisading; (b) spindle cells in a myxomatous stroma; (c) organoid structures resembling Vater-Pacinian corpuscles. 


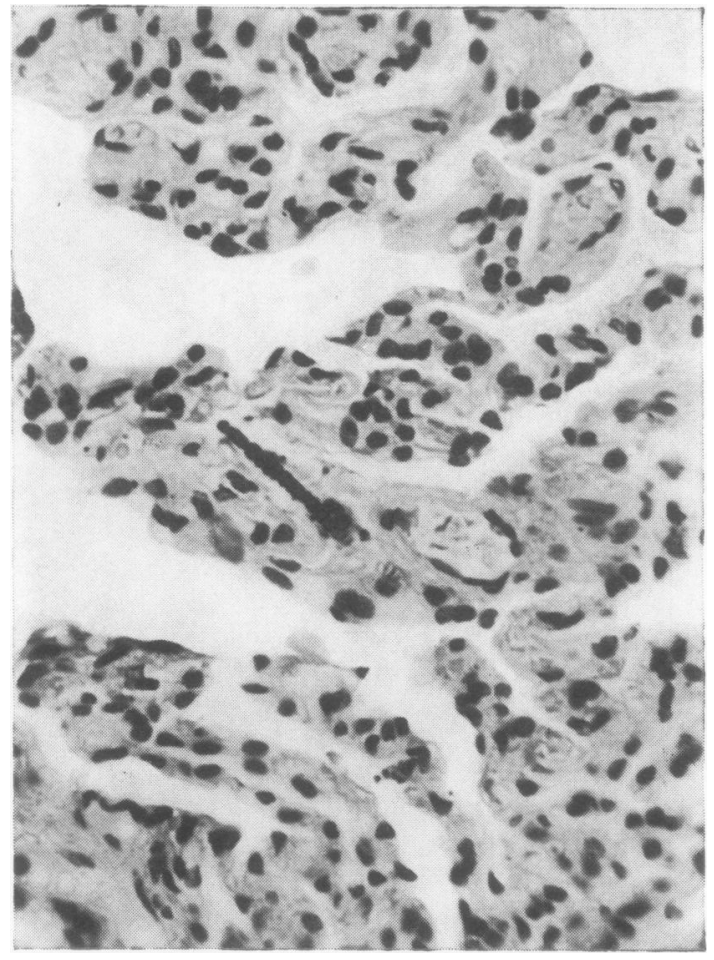

FIG. 5. Microscopical view of lung $(H . \& E . \times 330)$ showing an asbestos body.

which varied considerably from place to place, was composed mainly of interlacing fascicles and whorls of pleomorphic spindle cells. There was some nuclear regimentation (Antoni A) (Fig. 4a) while in other areas the cells were more loosely arranged in a myxomatous stroma (Antoni B) (Fig. 4b). Distinct organoid structures bearing a striking resemblance to Vater-Pacinian corpuscles were also present (Fig. 4c). Necrosis and mitotic activity were not prominent features and there were no tumour giant cells. The satellite nodules in the lung and pleura had a similar appearance. Special stains were unhelpful in identifying this tumour but fine reticular fibres appeared to run parallel to the spindle cells and did not surround them. The lung tissue away from the tumour contained many asbestos fibres (Fig. 5) and there was mild fibrosis of the alveolar walls.

On this evidence the diagnosis of primary intrapulmonary neurogenic sarcoma and asbestosis was made.

\section{DISCUSSION}

There is considerable divergence of opinion in the literature regarding the definition, nomenclature, and diagnostic criteria of neurogenic sarcomas. We regard such tumours as sarcomas in which there are sufficiently characteristic areas to indicate an origin from nerve sheath, and on $\frac{}{\bar{N}}$ such grounds there might be a case for adopting $\frac{\pi}{\vec{T}}$ the term malignant Schwannoma. However, until $\varrho$ the histogenesis of such tumours is universally $\nRightarrow$ accepted the less specific term seems appropriate. $\vec{\circ}$ Moreover, since, as Willis (1967) points out, Schwann cells form collagen, the appearance of $\vec{\omega}$ such tumours can range from the distinctly neural, through mixed types, to growths resemb- $\vec{x}$ ling ordinary fibrosarcomas. In view of the difficulty in determining the exact origin of the $i$ latter group of tumours, only cases which fulfil iv the criteria suggested by Neilson (1958) can be $\vec{N}$ accepted as neurogenic. The tumours are com- 을 posed of interweaving fascicles of spindle cells $\rightarrow$ but show areas of nuclear regimentation resemb- $\bar{z}$ ling Antoni type A and have a loose myxomatous arrangement resembling Antoni type $B$ in other parts. Organoid structures have been present in $\vec{v}$ the five acceptable cases to date and in the present case. Spencer (1968) claims that such structures o do not appear in benign intrapulmonary neurinomas. The present case conforms to the histological pattern of the previous reports and is thus presented as the sixth authentic case of neurogenic sarcoma.

The male/female ratio in these six cases is $5: 1$ with an average age of onset of 43 years. The presenting symptoms and radiological features were similar to those of bronchogenic carcinoma which was the usual preoperative diagnosis 을 (Table). However, in our case the history of $x$ exposure to asbestos and the associated hyper- $\frac{0}{3}$ trophic pulmonary osteoarthropathy led to an initial diagnosis of mesothelioma of the visceral pleura. The association of mesothelioma with asbestos exposure is well recognized (Wagner, 은 Sleggs and Marchand, 1960 ; Owen, 1965) and $D$ hypertrophic pulmonary osteoarthropathy has been found in up to $50 \%$ of patients with solitary $N$ pleural tumours (Benoit and Ackerman, 1953). Elmes, McCaughey, and Wade (1965) defined 'heavy exposure' to asbestos as 'a definite history $\mathrm{W}$ of working with asbestos full time for at least 1 r year', and on this definition the exposure to asbestos in our patient was obviously very heavy $\mathbb{\Phi}$ over a period of 20 years. He had developed $\stackrel{\mathcal{f}}{+}$

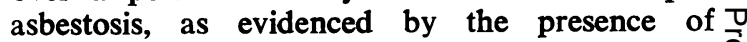
hyaline pleural plaques, asbestos bodies in the lung, and pulmonary interstitial fibrosis $\stackrel{\mathbb{T}}{\mathbb{P}}$ (Hourihane, Lessof, and Richardson, 1966), but $\stackrel{\AA}{\AA}$ it is not known whether this had any connexion $\overline{0}$ with the development of the tumour. A history 
T A B L E

ACCEPTED CASES OF PRIMARY INTRAPULMONARY NEUROGENIC SARCOMA

\begin{tabular}{|c|c|c|c|c|c|c|}
\hline Authors & Sex & $\begin{array}{l}\text { Age } \\
\text { (yr) }\end{array}$ & $\begin{array}{c}\text { Anatomical } \\
\text { site }\end{array}$ & Symptoms & Microscopical appearance & $\begin{array}{l}\text { Treatment and } \\
\text { prognosis }\end{array}$ \\
\hline $\begin{array}{l}\text { Diveley and } \\
\text { Daniel } \\
\text { (1951) } \\
\text { Santy } \text { et al. } \\
\text { (1953) }\end{array}$ & $\mathbf{M}$ & 48 & $\begin{array}{l}\text { LUL } \\
\text { RLL }\end{array}$ & $\begin{array}{l}\text { Malaise, weight loss, } \\
\text { anaemia } \\
\text { Haemoptysis }\end{array}$ & $\begin{array}{l}\text { Pleomorphic spindle cells, } \\
\text { palisading and whorls; numerous } \\
\text { mitotic figures } \\
\text { Fusiform cells, areas of xantho- } \\
\text { matous degeneration; reticulum } \\
\text { fibres surrounding cells }\end{array}$ & $\begin{array}{l}\text { Pneumonectomy: died } \\
4 \text { months later from } \\
\text { metastases } \\
\text { Cured by } \\
\text { pneumonectomy }\end{array}$ \\
\hline $\begin{array}{c}\text { Petriat et al. } \\
\text { (1953) }\end{array}$ & $\mathbf{M}$ & 63 & $\mathbf{L L L}$ & Asymptomatic & $\begin{array}{l}\text { Fusiform cells arranged in whorls; } \\
\text { palisading of nuclei; } \\
\text { mitotic figures }\end{array}$ & Cured by lobectomy \\
\hline Neilson (1958) & $\mathbf{M}$ & 35 & LLL & $\begin{array}{l}\text { Cough, haemoptysis, } \\
\text { chest pains }\end{array}$ & $\begin{array}{l}\text { Fusiform cells in interweaving } \\
\text { bundles; fascicular pattern with }\end{array}$ & Cured by lobectomy \\
\hline $\begin{array}{l}\text { Bartley and } \\
\text { Arean } \\
(1965)\end{array}$ & $\mathbf{M}$ & 19 & LUL & $\begin{array}{l}\text { Joint pains, weight } \\
\text { loss, leg oedema }\end{array}$ & $\begin{array}{l}\text { Spindle cells arranged in bundles } \\
\text { and whorls with an organized } \\
\text { pattern; reticulum fibrils; } \\
\text { areas of necrosis; mitotic } \\
\text { figures }\end{array}$ & $\begin{array}{l}\text { Cured by } \\
\text { pneumonectomy }\end{array}$ \\
\hline Present case & $\mathbf{M}$ & 43 & RLL & $\begin{array}{l}\text { Chest pains, joint } \\
\text { pains and effusions, } \\
\text { finger clubbing }\end{array}$ & $\begin{array}{l}\text { Spindle cells in whorls, nuclear } \\
\text { palisading, organoid structures; } \\
\text { fine reticular fibres parallel to } \\
\text { cells }\end{array}$ & $\begin{array}{l}\text { Lobectomy; died } 16 \\
\text { months later from } \\
\text { metastases }\end{array}$ \\
\hline
\end{tabular}

of exposure to asbestos was not given in any of the previous five cases.

Joint pains were a presenting feature in the case reported by Bartley and Arean (1965) who described a 19-year-old boy with a two-month history of aching pains in the wrists, elbows, and knees. The joints were hot but not swollen. He also complained of soreness in the anterior tibial region and forearms and of swelling of the feet. Radiographs of the long bones were normal. After left pneumonectomy to remove a large tumour of the left upper lobe, the limb and joint pains had disappeared on recovery from anaesthesia. While tinger clubbing and periosteal new bone formation were not seen, it appears likely that hypertrophic pulmonary osteoarthropathy was present in an early form although it is not described as such in their case report. In our case the triad of (1) periosteal new bone formation on the distal ends of long bones, (2) joint swelling, pain, and tenderness, and (3) clubbing of the fingers, were present and established the diagnosis of hypertrophic pulmonary osteoarthropathy. Their association with the tumour is evident in that they rapidly disappeared when the tumour was removed. When metastases occurred the clubbing reappeared.

Pulmonary osteoarthropathy has been described in association with a wide variety of tumours, including bronchogenic carcinoma (Vogl, Blumenfeld, and Gutner, 1951 ; Semple and McCluskie, 1955; Berman, 1963), pleural mesothelioma (Berg, 1949), carcinoma of the nasopharynx (Compere, Adams, and Compere, 1935), carcinoma of the thymus (Miller, 1939), neoplasms of the upper gastrointestinal tract including myxoma of the oesophagus (Hollis, 1967), and chronic myeloid leukaemia (Temple and Jaspin, 1948). It has been reported in three out of six cases of neurolemmoma of the diaphragm (Trivedi, 1958) but not previously with a pulmonary tumour of neurogenic origin. Currently two theories, the endocrine and the neurogenic, are advanced to explain the occurrence of the arthropathy. The existence of an underlying endocrine imbalance was suggested by Ginsburg and Brown (1961) who measured urinary oestrogen levels in male patients with bronchogenic carcinoma and hypertrophic pulmonary arthropathy. They found in such patients that the mean oestrogen excretion was more than twice that of healthy men; after removal of the tumour it fell to normal. The neurogenic theory arose from the observations of Flavell (1956) that regression of the arthropathy occurred after section of the vagal fibres to the lung even when the bronchogenic carcinoma was not removed. Experimental evidence which partially supported Flavell's findings was put forward by Holling, Brodey, and Boland (1961) ; and Holling, Danielson, Hamilton, Blakemore, and Brodey (1963), who postulated that impulses arose in the vagus nerve (Holling, 1967). The efferent path of the 'reflex' did not appear to be neural but they were unable to find evidence for a simple humoral mechanism to explain the increased limb blood flow which is a constant feature in osteoarthropathy (Ginsburg, 1958 ; Holling et al., 1961). Our case seems to support this theory for it is easy to imagine afferent nervous impulses 
arising in a primary neurogenic sarcoma of the lung, and the patient's joint pains were relieved abruptly by excision of the tumour with division of the perihilar vagal nerve fibres. Moreover, despite the recurrence of the tumour in the pleura, ribs, and mediastinum, the arthropathy did not reappear. If a humoral substance produced by the tumour was the direct cause of the arthropathy, then the joint pains and swelling should have reappeared with the development of the metastases.

Treatment in all six cases was by surgical removal. In four this appeared to be curative but the patient of Diveley and Daniel (1951) died four months after operation from metastases. The tumour recurred in our patient 5 months after operation, responded poorly to radiotherapy, and caused the patient's death from metastases 16 months after operation.

Our thanks are due to Mr. H. M. Stevenson, F.R.C.S., for permission and encouragement to report this case. Dr. A. R. Lyons, M.D., F.R.C.P., F.F.R. R.C.S.I., D.M.R.T., looked after this patient in the later stages of his illness and gave us much helpful information for which we are most grateful. We wish also to thank Miss N. Sewell and Miss A. Hillary for secretarial help.

\section{REFERENCES}

Bartley, T. D., and Arean, V. M. (1965). Intrapulmonary neurogenic tumours. J. thorac. cardiovasc. Surg., 50, 114.

Benoit, H. W. and Ackerman, L. V. (1953). Solitary pleural mesotheliomas. J. thorac. Surg., 25, 346.

Berg, R. (1949). Arthralgia as a first symptom of pulmonary lesions. Dis. Chest, 16, 483.

Berman, B. (1963). Pulmonary hypertrophic osteoarthropathy. Arch intern. Med., 112, 947.

Compere, E. L., Adams, W. E., and Compere, C. L. (1935). Generalised hypertrophic osteoarthropathy. Surg. Gynaec. Obstet., 61, 312.

Diveley, W., and Daniel, R. A. (1951). Primary solitary neurogenic tumors of the lung. J. thorac. Surg., 21, 194.

Elmes, P. C., McCaughey, W. T. E., and Wade, O. L. (1965). Diffuse mesothelioma of the pleura and asbestos. Brit. med.J., 1, 350.

Flavell, G. (1956). Reversal of pulmonary hypertrophic osteoarthropathy by vagotomy. Lancet, 1, 260.
Ginsburg, J. (1958). Observations on the peripheral circulation in hypertrophic pulmonary osteoarthropathy. Quart. J. Med., 27, 335.

and Brown, J. B. (1961). Increased oestrogen excretion $\frac{\bar{\sigma}}{\omega}$ in hypertrophic pulmonary osteoarthropathy. Lancet, $\vec{\nabla}$ 2, 1274.

Holling, H. E. (1967). Pulmonary hypertrophic osteoarthro- ڤ్ pathy. Ann. intern. Med., 66, 232.

Brodey, R. S., and Boland, H. C. (1961). Pulmonary $\vec{\circ}$ hypertrophic osteoarthropathy. Lancet, 2, 1269.

— Danielson, G. K., Hamilton, R. W., Blakemore, W. S., and Brodey, R. S. (1963). Hypertrophic pulmonary osteoarthropathy. J. thorac. cardiovasc. Surg., 46, 310. $\overrightarrow{\times}$

Hollis, W. C. (1967). Hypertrophic osteoarthropathy î secondary to upper-gastrointestinal-tract neoplasm. of Case report and review. Ann. intern. Med., 66, 125.

Hourihane, D. O'B., Lessof, L., and Richardson, P. C. $\frac{N}{N}$ (1966). Hyaline and calcified pleural plaques as an index of exposure to asbestos. Brit. med. J., 1, 1069.

Miller, E. R. (1939). Carcinoma of the thymus with marked pulmonary osteo-arthropathy. Radiology, 32, 651 .

Neilson, D. B. (1958). Primary intrapulmonary neurogenic $\frac{\Omega}{\sigma}$ sarcoma. J. Path. Bact., 76, 419.

Owen, W. G. (1965). Mesothelial tumors and exposure to asbestos dust. Ann. N.Y. Acad. Sci., 132, 674.

Petriat, A., Cornet, L., Legar, H., Castaing, R., and Tessier, R. (1953). Neurinome primitif intra-pulmonaire. Presse méd., 61, 1526.

Santy, P., Galy, P., Touraine, R., and Uguat (1953). Les tumeurs nerveuses primitives intra-pulmonaires. $J$. franc. Méd. Chir. thor., 7, 490.

Semple, T., and McCluskie, R. A. (1955). Generalised @ hypertrophic osteoarthropathy in association with $\overrightarrow{\vec{B}}$ bronchial carcinoma: a review based on 24 cases. $\frac{3}{3}$ Brit. med. J., 1, 754.

Spencer, H. (1968). Pathology of the Lung, 2nd ed., pp. 886-888. Pergamon Press, Oxford.

Temple, H. L., and Jaspin, G. (1948). Hypertrophic osteoarthropathy. Amer. J. Roentgenol., 60, 232.

Trivedi, S. A. (1958). Neurilemmoma of the diaphragm $\stackrel{x}{\sim}$ causing severe hypertrophic pulmonary osteoarthro- $\bar{\sigma}$ pathy. Brit. J. Tuberc., 52, 214.

Vogl, A., Blumenfeld, S., and Gutner, L. B. (1951). Diagnostic significance of pulmonary hypertrophic osteoarthro- $\frac{\mathrm{O}}{3}$ pathy. Amer. J. Med., 18, 51.

Wagner, J. C., Sleggs, C. A., and Marchand, P. (1960). 윽 Diffuse pleural mesothelioma and asbestos exposure in north western Cape Province. Brit. J. industr. Med.,을 17, 260.

Willis, R. A. (1967). Pathology of Tumours, 4th ed., pp. 852-854. Butterworths, London. 